\title{
IN MEMORIAM: PROF. DR. HABIL. ADOLFAS BAUBLYS (1941-2016)
}

It is with deep regret that we announce on the passing away

of Prof. Dr. Habil. Adolfas Baublys, age of 75, on 28 November 2016.

He was the Founder and the First Editor-in-Chief of the Research Journal TRANSPORT.

His cheerful eyes, his smile, his great mind, his humour, were legendary and made him a unique tireless transport science communicator.

Our lives are smaller without Prof. Dr. Habil. Adolfas Baublys. He will be missed. He will always remain in our hearts.

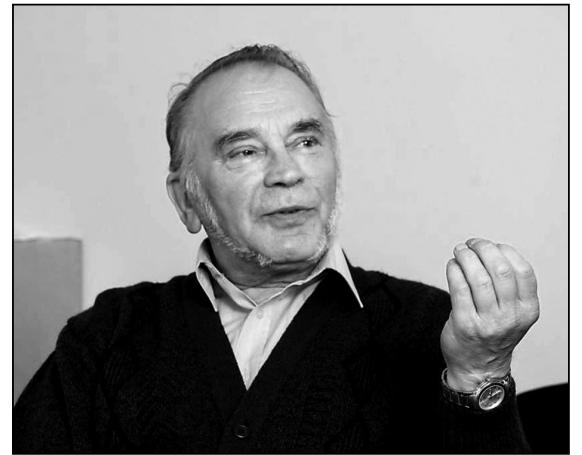

Adolfas Baublys - professor emeritus, doctor habilitatus, the Founder of the Research Journal TRANSPORT in 1986 and its Editor-in-Chief (1986-2013), Honorary Editor-in-Chief (2013-2016).

Prof. Adolfas Baublys was a well known scientist, a developer and established authority of transport science in Lithuania. During the period of his scientific activities he had published 8 monographs, 16 textbooks, 230 scientific publications. 2 scientists had defended doctor habilitatus dissertations and 22 - doctoral dissertations, under his supervision. He was a chairman or a member in 9 habilitation committees and in 32 doctoral studies committees.

Prof. Adolfas Baublys created a theoretical framework of Lithuanian transport system, suggested guiding principles of Lithuanian transport policy, created modelling methodologies for the vehicle fleet management and freight flow.
He was an Initiative Founder of Lithuanian National Association of Forwarders and Logistics (LINEKA) and was a President of this association (1993-1996) and Honorary President (2013-2016).

In 1966 he was granted a republican prize Laureate of Lithuania for his scientific work entitled 'Development of a very high precision circular grinding machine 3E153 and a universal very high precision circular grinding machine 3E12 and their application to manufacture?.

Considering his scientific achievements Prof. Adolfas Baublys was elected as a Member-Expert to the Lithuanian Academy of Sciences in 1991. Since 2000, the Professor was a Chairman of the Presidium of Transportation Research Board of the Lithuanian Academy of Sciences.

In 2000 together with a Prof. Ramūnas Palšaitis he was granted an award for their work 'The strategy of forming Lithuanian transport system: theoretical and methodological aspects (1988-1999)'.

In 2000 he was awarded a Medal of Merit to Vilnius Gediminas Technical University.

In 2001 he was awarded a Medal of Honour of 'Integral humanization' for the propagation of human values to all social and private spheres of life.

In 2006 he was awarded a Bronze Medal on the 50th Anniversary of Vilnius Gediminas Technical University.

In 2011 he was granted a Professor Emeritus title in the Senate meeting of Vilnius Gediminas Technical University. 


\section{The Memories about a Research Journal TRANSPORT by the Professor ${ }^{*}$}

It is a story about one of the most important work in my life and I want to give a brief history of the Journal TRANSPORT.

At that time (1980-1985), there was no edition in the area of transport at VCEI - Vilnius Civil Engineering Institute (the former title of VGTU - Vilnius Gediminas Technical University). In order for something like that to come to an existence and to obtain a special permission from the Higher and Special Education Ministry of LSSR, a lot of organizational work was required.

I started thinking about how to overcome these barriers. Then, I went to Jonas Černikovas, a Minister of Highway and Road Transport, and I had proven quite easily that there was a need for an edition in the area of transport. The Minister made a call to Henrikas Zabulis, a Minister of Higher and Special Education of LSSR, and convinced him that such edition in the area of transport could be published at VCEI. A special document of Jonas Černikovas was prepared for Henrikas Zabulis, who made some of his employees responsible to inform Aleksandras Čyras a Rector of VCEI. That is how the First Edition of the Journal TRANSPORT was brought out.
As Proceedings of the Higher Schools in Lithuania: Автомобильный транспорт / Automobiliu transportas [Automobile Transport] it was being published once a year during the period 1986-1991. Papers were published in Russian language, their abstracts in both Lithuanian and English.

In 1992-1994 the Journal was published as Proceedings of Vilnius Technical University: Transportas / Transport Engineering. The papers were in Lithuanian, English and Russian languages.

In 1995-2002 the Journal became a Research Journal of Vilnius Gediminas Technical University and Lithuanian Academy of Sciences: Transportas / Transport Engineering / Транспорm. During this period, 6 editions were published in English language.

From 2002 to 2005, the Journal was renamed to Transport and papers were presented in English language only.

Since 2011, the Journal is being published by Vilnius Gediminas Technical University and Taylor \& Francis 4 times a year.

The Research Journal TRANSPORT is published not only as a print-edition but it is also available in electronic form. The Journal is abstracted and indexed in 16 international databases.

Prepared by Prof. Dr. Olegas Prentkovskis, Editor-in-Chief of the Research Journal TRANSPORT

*Source: Permainų ir iššūkių keliu: Vilniaus Gedimino technikos universiteto profesorių emeritų prisiminimai. 2016. Vilnius: Technika (in Lithuanian). 